\title{
Yvonne Bargues Rollin, Une minute, une seconde, un quart de seconde: vision photographique dans la Bête humaine de Zola
}

\section{Chiara Lanciano}

\section{(2) OpenEdition Journals}

\section{Édition électronique}

URL : http://journals.openedition.org/studifrancesi/9015

DOI : 10.4000/studifrancesi.9015

ISSN : 2427-5856

Éditeur

Rosenberg \& Sellier

\section{Édition imprimée}

Date de publication : 1 octobre 2008

Pagination : 485

ISSN : 0039-2944

\section{Référence électronique}

Chiara Lanciano, «Yvonne Bargues Rollin, Une minute, une seconde, un quart de seconde: vision photographique dans la Bête humaine de Zola », Studi Francesi [En ligne], 155 (LII | II) | 2008, mis en ligne le 30 novembre 2015, consulté le 14 janvier 2021. URL : http://journals.openedition.org/studifrancesi/ 9015 ; DOI : https://doi.org/10.4000/studifrancesi.9015

Ce document a été généré automatiquement le 14 janvier 2021.

\section{cc) (†) $\odot$}

Studi Francesi è distribuita con Licenza Creative Commons Attribuzione - Non commerciale - Non opere derivate 4.0 Internazionale. 


\title{
Yvonne Bargues Rollin, Une minute, une seconde, un quart de seconde: vision photographique dans la Bête humaine de Zola
}

\author{
Chiara Lanciano
}

\section{RÉFÉRENCE}

YVONNE BARGUES ROLLIN, Une minute, une seconde, un quart de seconde: vision photographique dans la Bête humaine de Zola, «Romantisme: L'élection au XIX siècle», n. 135, Paris, Armand Colin, mars 2007, pp. 87-97.

1 Temps et regard sont des vecteurs cruciaux dans la Bête Humaine et dans l'enquête judiciaire menée par le chef de file du naturalisme. Le jeu du regard, tout comme celui d'ombre et de lumière ont une importance notable: Jacques, à la fois témoin d'un meurtre et chargé, de par sa fonction, de veiller à la vie des passagers de son train, est réduit à un simple regard. Il est le principal «regardeur-voyeur» du naturaliste tel que le décrit Philippe Hamon dans Le Personnel du roman, qui attise chez le "personnagespectateur» le désir fou de voir. La Bête Humaine est aussi, selon Yvonne Bargues Rollin, «le roman du Temps par excellence» où la seconde devient une entité toute puissante, où un instant suffit pour manquer son train et attendre une éternité le prochain, où un instant suffit à Jacques pour passer de la préméditation à l'acte même. «La seconde représente dans le Bête Humaine l'Instant, dans sa fluidité et dans sa fugacité», dans son effet d'instantané: ultime et fatidique seconde, qui est essentiellement le produit du hasard, de l'inattendu, qui sauve la vie de la victime à deux reprises mais que Jacques finit par saisir, lorsqu'il tue sa maîtresse assouvissant ainsi ses pulsions meurtrières. L'A. de l'article conclut que la vision instantanée qui déclenche l'acte final, le crime, est une «vision photographique»: un instantané de deux moments fatidiques en équilibre. 
Répondant à une pulsion, Jacques saisit l'immortalité d'un instant suprême, dépasse le réel de son quotidien de cheminot, pour entrer dans le monde du fantastique et posséder sa maîtresse dans l'éternité. 